\title{
POLA PENGGUNAAN ANTIBIOTIK PROFILAKSIS PADA PASIEN BEDAH SESAR (SECTIO CAESAREAN) DI RUMAH SAKIT ISLAM SAMARINDA
}

\author{
Elsha Wiguna Sumanti*, Welinda Dyah Ayu, Rolan Rusli \\ Fakultas Farmasi Universitas Mulawarman, Samarinda, Kalimantan Timur \\ *Email: elshawiguna@gmail.com
}

\begin{abstract}
ABSTRAK
Angka kejadian kelahiran dengan bedah sesar meningkat setiap tahunnya, sehingga kebanyakan pasien bedah sesar diberikan antibiotik profilaksis untuk mencegah kejadian infeksi luka operasi (ILO). Penelitian ini bertujuan untuk mengetahui pola penggunaan antibiotik profilaksis pada pasien bedah sesar di Rumah Sakit Islam Samarinda. Pengambilan data dilakukan secara retrospektif menggunakan rekam medik pasien. Data hasil penelitian yang diperoleh dianalisis secara deskriptif. Adapun kriteria inklusi pasien yang digunakan adalah pasien yang melahirkan secara bedah sesar dan pasien yang memiliki data rekam medik yang lengkap. Hasil penelitian menunjukkan bahwa karakteristik pasien bedah sesar berdasarkan usia tertinggi pada usia 20-35 tahun sebanyak 78,14\% (118 pasien), sebanyak 35,09\% (53 pasien) berdasarkan frekuensi kehamilan tertinggi pada kehamilan kedua, serta berdasarkan indikasi medis tertinggi pada bedah sesar berulang sebanyak 33,77\% (51 pasien). Gambaran penggunaan antibiotik yang digunakan tertinggi adalah sefotaksim sebanyak 73,50\% (111 pasien), 15,23\% (23 pasien) mendapatkan seftriakson, 0,66\% (1 pasien) mendapatkan amoksisilin, 0,66\% (1 pasien) mendapatkan sefoperazon dan 9,93\% pasien (15 pasien) tidak mendapatkan antibiotik. Pola penggunaan antibiotik profilaksis pada pasien bedah sesar di Rumah Sakit Islam Samarinda tertinggi adalah sefotaksim $(73,50 \%)$.
\end{abstract}

Kata Kunci : antibiotik, profilaksis, sefotaksim

\begin{abstract}
The incidence of birth by caesarean section to increase each year, so most patients are given an antibiotic prophylactic cesarean section to prevent the incidence of surgical site infection (ILO). This study aims to determine the pattern of use of prophylactic antibiotics in patients with cesarean section at the Islam Hospital Samarinda. Data were collected using medical records retrospectively of patients. Research data were analyzed descriptively. The patient inclusion criteria used were patients delivered by cesarean section and the patients who had a complete medical record. The results showed that the characteristics of the patients the highest cesarean sections based on age at 20-35 years old as much as $78.14 \%$ (118 patients), as much as $35.09 \%$ (53 patients) based on the highest frequency of pregnancy in the second pregnancy, and based on medical indications highest repeat cesarean sections as much as $33.77 \%$ (51 patients). Overview highest use of antibiotics used was cefotaxime as much as $73.50 \%$ (111 patients), $15.23 \%$ (23 patients) received ceftriaxone, $0.66 \%$ (1 patient) received amoxicillin, $0.66 \%$ (1 patient) received sefoperazon and $9.93 \%$ of patients (15 patients) did not receive antibiotics. The pattern of
\end{abstract}


prophylactic antibiotics in patients with cesarean section at the Islam Hospital Samarinda was cefotaxime $(73.50 \%)$.

Keywords : antibiotic, prophylaxis, cefotaxime

\section{PENDAHULUAN}

WHO memperkirakan bahwa angka kejadian persalinan dengan bedah sesar sekitar 1015\% dari semua proses persalinan. Di Negara maju seperti Amerika Serikat terjadi peningkatan persentase kejadian bedah sesar, pada tahun 1970 total persalinan bedah sesar mencapai 5,5\%, tahun 1988 sebesar 24,7\%, tahun 1996 sebesar 20,7\% dan pada tahun 2006 sebesar 31,1\%. Di Indonesia terjadi peningkatan persalinan bedah sesar dari tahun 2001 sampai 2006 yairu sebesar 17\% meningkat menjadi 27,3\%. Kejadian bedah sesar disetiap daerah berbeda-beda, untuk daerah Solo kejadiannya mencapai 55\% sedangkan di Denpasar 18,2\%, hal ini dipengaruhi faktor ekonomi pasien (Rasjidi, 2009).

Antibiotik profilaksis dianjurkan pada persalinan bedah sesar karena dapat mencegah atau mengurangi kejadian infeksi yang disebabkan oleh kuman pada saat operasi.Agen antibiotik profilaksis yang sering digunakan dalam persalinan bedah sesar yaitu golongan penisilin (ampisilin) dan golongan sefalosporin generasi I (sefazolin).Antibiotik tersebut telah terbukti efektif sebagai antibiotik profilaksis pada bedah sesar (Smaill and Gyte, 2010).

Berdasarkan hasil penelitian sebelumnya oleh Mugford, et al., pada tahun 1989 menunjukkan bahwa penggunaan antibiotik profilaksis terbukti efektif dalam menurunkan kejadian infeksi dan juga dapat mengurangi biaya rumah sakit. Di Indonesia sendiri, penelitian tentang efektivitas profilaksis pada pasien bedah sesar di Rumah Sakit Sidoarjo menunjukkan bahwa penggunaan antibiotik profilaksis terbukti efektif sebesar $89,18 \%$, tidak efektif sebesar 4,05\% yang menunjukkan adanya infeksi dan 6,75\% tanpa keterangan. Antibiotik profilaksis yang digunakan yaitu seftriakson, sefitaksim dan sefotaksim (Prasetya, 2013).

Terjadinya resiko infeksi bedah sesar tersebut mendorong peneliti untuk melakukan penelitian tentang pola penggunaan antibiotik pada pasien bedah sesar.

\section{METODE PENELITIAN}

Data yang digunakan dalam penelitian ini berupa data sekunder yang diperoleh dari rekam medik pasien bedah sesar di RS Islam Samarinda dan memenuhi kriteria inklusi. Data yang diperoleh adalah usia, frekuensi kehamilan, indikasi medis pasien dan jenis antibiotik.

\section{HASIL DAN PEMBAHASAN}

\section{Karakteristik Pasien}

\section{Karakteristik Pasien Berdasarkan Usia}

Berdasarkan pengelompokan usia pasien bedah sesar di Rumah Sakit Islam Samarinda, pasien yang mengalami bedah sesar paling banyak terjadi pada pasien yang berusia 20-35 tahun. Hal ini dapat dilihat pada gambar 1. 


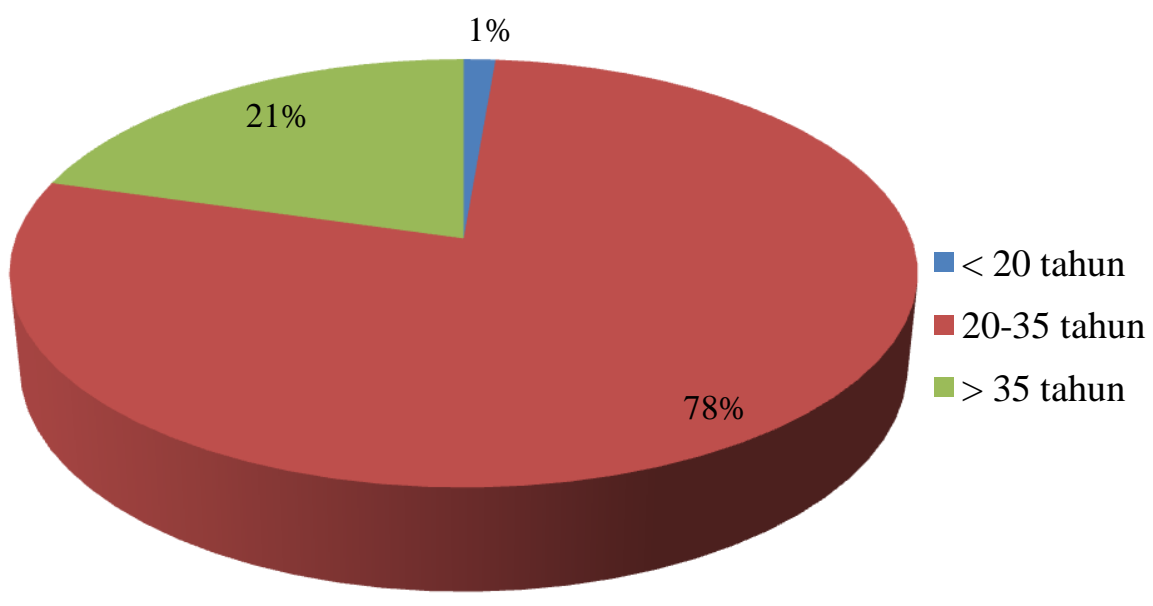

Gambar 1. Diagram Karakteristik Pasien Bedah Sesar di RS Islam Berdasarkan Usia

Dari gambar 1 menunjukkan bahwa pasien bedah sesar di Rumah Sakit Islam terbanyak adalah usia 20-35 tahun sebanyak 118 pasien. Dikarenakan usia juga dapat mempengaruhi proses persalinan, semakin tinggi usia seseorang maka akan semakin beresiko dalam proses persalinan. Menurut Depkes (2010) yang menyatakan dari segi kesehatan ibu yang berusia < 20 tahun rahim dan panggul belum berkembang dengan baik, begitu sebaliknya pada ibu yang berusia $>35$ tahun kesehatan dan keadaan rahim tidak sebaik seperti saat ibu berusia 20-35 tahun. Usia ibu $<20$ tahun dan $>35$ tahun merupakan usia yang tidak reproduktif atau usia tersebut termasuk dalam resiko tinggi kehamilan. Kehamilan di usia muda atau remaja di bawah 20 tahun akan mengakibatkan rasa takut terhadap kehamilan dan persalinan, hal ini disebabkan pada usia tersebut ibu mungkin belum siap untuk memiliki anak dan alat-alat reproduksi ibu belum siap untuk hamil. Begitu pula pada kehamilan di usia tua yaitu di atas 35 tahun akan menimbulkan kecemasan terhadap kehamilan dan persalinan serta alat-alat reproduksi ibu terlalu tua untuk hamil.

BKKBN (2007) mengemukakan bahwa pada usia kurang dari 20 tahun termasuk dalam kriteria terlalu muda dan usia lebih dari 35 tahun termasuk dalam kriteria terlalu tua, sehingga usia 20-35 tahun dianggap usia yang paling aman dan ideal untuk proses kehamilan dan melahirkan.

\section{Karakteristik Pasien Berdasarkan Status Paritas}

Frekuensi kehamilan atau status paritas pasien bedah sesar turut mempengaruhi angka kejadian bedah sesar.

Dari gambar 2 menunjukkan bahwa pasien yang menjalani bedah sesar terbanyak merupakan pasien dengan kehamilan yang kedua. Menurut Sheiner (2001) bahwa kejadian plasenta previa meningkat dengan meningkatnya paritas ibu. Konsep 'migrasi plasenta' yang menjadi predisposisi plasenta previa pada multipara. Migrasi plasenta disebabkan karena pada bagian tepi bawah plasenta mengalami atrofi sehingga kekurangan suplai darah yang menyebabkan plasenta tumbuh ke atas mencari suplai darah. Migrasi plasenta ini sesungguhnya tidak terjadi tetapi karena pergerakan ke atas akibat pembentukan segmen bawah rahim sehingga seolah-olah plasenta bermigrasi. Riwayat kehamilan sebelumnya menyebabkan plasenta terletak lebih rendah dengan mekanisme lain. Tingginya resiko terjadi plasenta previa inilah yang menyebabkan angka kejadian bedah sesar pada primipara dan multipara lebih tinggi dibandingkan dengan ibu yang belum pernah melahirkan. 


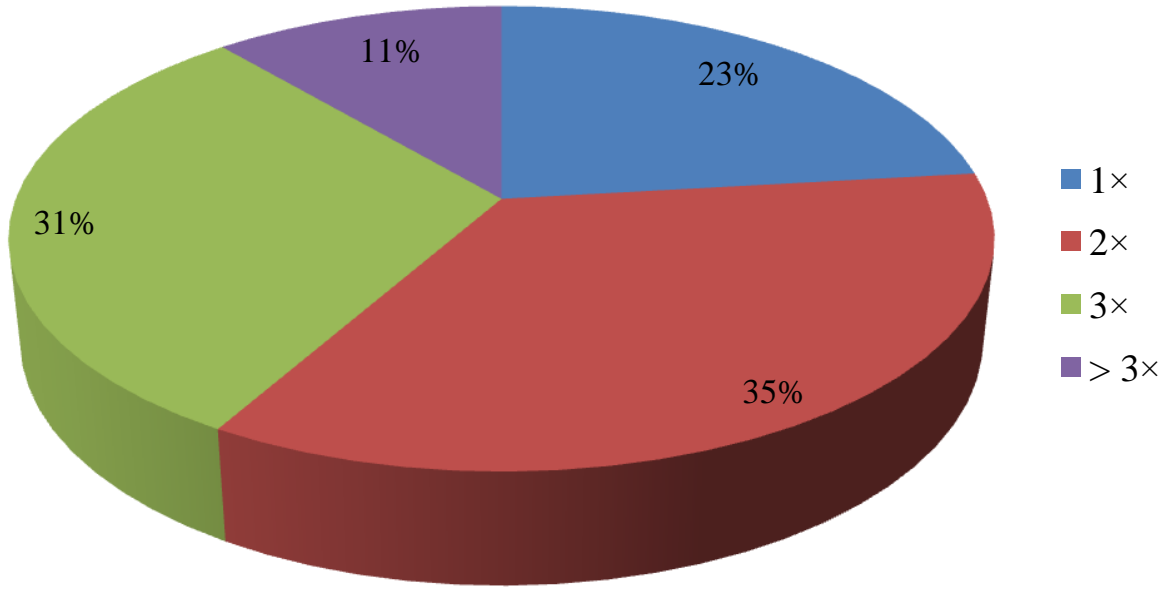

Gambar 2. Karakteristik Pasien Bedah Sesar di RS Islam Berdasarkan Status Paritas

Menurut Gordon (2012) wanita primipara (pernah satu kali melahirkan bayi) lebih beresiko terjadi komplikasi kehamilan dan persalinan serta lebih tinggi angka kejadian bedah sesar. Resiko kejadian plasenta previa meningkat dengan meningkatnya paritas ibu. Pada wanita multipara (telah melahirkan 2 bayi), kejadian yang mengindikasikan tindakan bedah sesar 3 kali lebih sering daripada primipara. Misalnya kejadian plasenta previa pada wanita multipara disebabkan kurangnya vaskularisasi dan perubahan atrofi akibat persalinan sebelumnya. Kejadian plasenta previa tiga kali lebih sering pada wanita multipara daripada primipara. Pada multipara, plasenta previa disebabkan vaskularisasi yang berkurang dan perubahan atrofi akibat persalinan masa lampau. Aliran darah ke plasenta tidak cukup dan memperluas permukaannya sehingga menutupi pembukaan jalan lahir (Sumapraja dan Rachimhadi, 2005).

\section{Karakteristik Pasien Berdasarkan Indikasi Medis}

Indikasi medis pada pasien bedah sesar di Rumah Sakit Islam Samarinda cukup beragam. Dapat dilihat pada gambar 3.

Dari gambar 3 menunjukkan bahwa indikasi medis pasien bedah sesar di Rumah Sakit Islam Samarinda terbanyak adalah riwayat SC atau bedah sesar berulang. Pasien yang memiliki riwayat bedah sesar pada persalinan sebelumnya tidak harus melahirkan secara bedah sesar pada persalinan selanjutnya jika memenuhi syarat persalinan pervaginam. VBAC (Vaginal Birth After Cesarean) tidak dapat dilakukan pada bekas bedah sesar jika insisi bedah sesar yang lalu berupa insisi corporal, sudah 2 kali melakukan bedah sesar dan terdapat janin besar atau disproporsi sevalopelvik. Persalinan pervaginam pada bekas bedah sesar kurang dari 18 bulan memiliki resiko ruptur uteri yang lebih tinggi.

Tingginya persalinan dengan bedah sesar berulang di Rumah Sakit Islam Samarinda, dapat dikarenakan oleh penatalaksaan persalinan ibu bekas bedah sesar didahului dengan seleksi yang ketat dalam pemilihan cara persalinan, terutama pada ibu yang akan menjalankan persalinan pervaginam. Selain itu, selama persalinan percobaan pervaginam pada ibu dengan bekas bedah sesar dilakukan observasi yang lebih ketat. Apabila terjadi 
kemacetan persalinan atau bayi mengalami gawat janin, maka kehamilan segera diakhir dengan bedah sesar berulang untuk menyelamatkan ibu dan janin (Caughey, 2001).
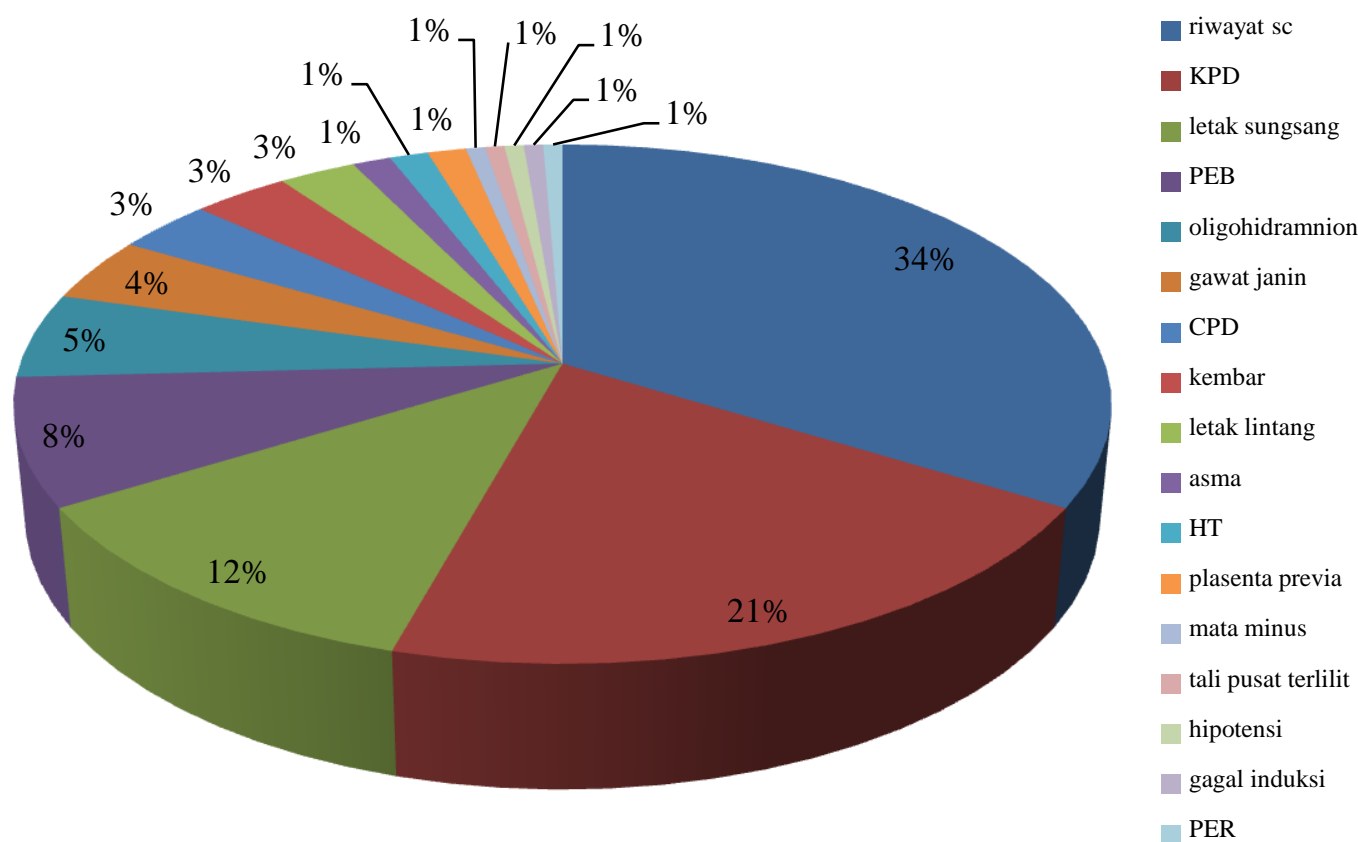

Gambar 3. Karakteristik Pasien Bedah Sesar di RS Islam Berdasarkan Indikasi Medis

\section{Pola Penggunaan Antibiotik Profilaksis}

Dari data yang dikumpulkan didapatkan antibiotik profilaksis yang digunakan di Rumah Sakit Islam Samarinda cukup beragam, yaitu sefotaksim, seftriakson, sefoperazon dan amoksisilin. Bahkan pada beberapa pasien tidak mendapatkan antibiotik profilaksis. Hal ini dapat dilihat pada gambar 4 .

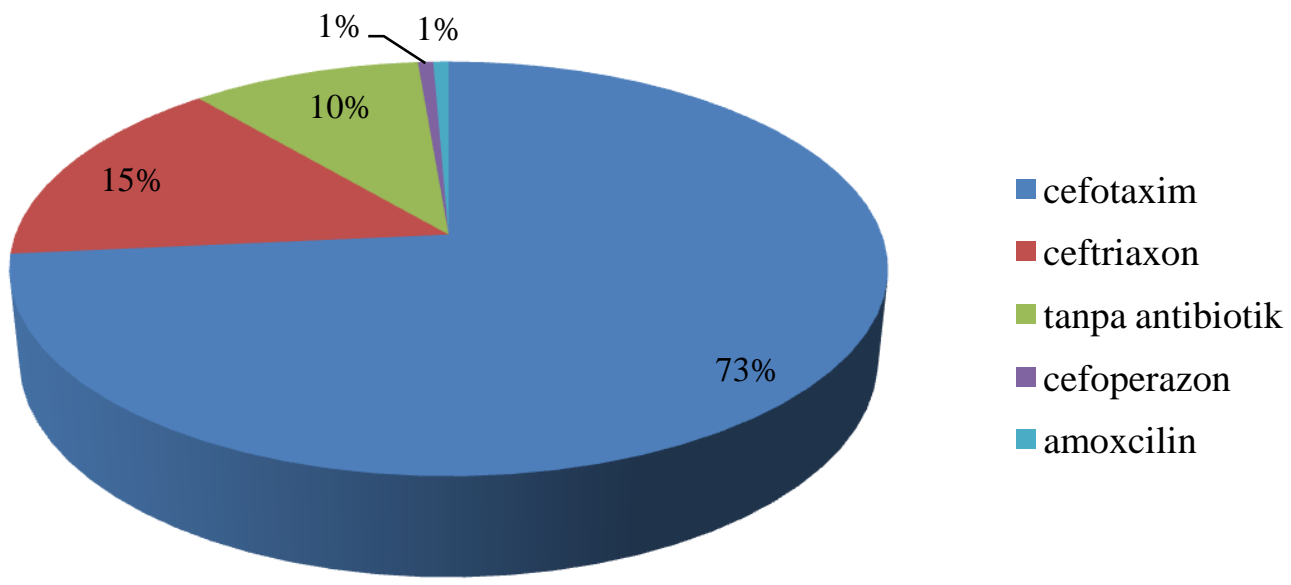

Gambar 4. Pola Penggunaan Antibiotik Profilaksis Pada Pasien Bedah Sesar Di RS Islam 
Dari gambar 4 menunjukkan bahwa lebih dari separuh pasien menerima antibiotik profilaksis dari golongan sefalosporin yaitu sefotaksim, seftriakson dan sefoperazon. Namun ada pasien yang menerima antibiotik profilaksis dari golongan penisilin, yaitu amoksisin. Jenis antibiotik ß-laktam yang biasa digunakan untuk profilaksis bedah ialah golongan sefalosporin dan penisilin. Sefalosporin ini aktif terhadap kuman gram positif maupun gram negatif. Mekanisme kerja umum dari sefalosporin yaitu menghambat sintesis dinding sel mikroba, dengan cara menghambat reaksi transpeptidase tahap ketiga dala rangkaian reaksi pembentukan dinding sel sehingga bakteri akan mengalami lisis. Namun kepekaan terhadap betalaktamasenya yang lebih rendah daripada penisilin (Hoan Tjai, 2002). Dalam penelitian ini di ketahui antiibiotik profilaksis yang digunakan antara lain sefotaksim, seftriakson dan sefoperazon yang merupakan antibiotik golongan sefalosporin generasi ketiga. Antibiotik sefalosporin generasi ketiga merupakan antibiotik yang mempunyai daya kerja spektrum luas yang efektif terhadap bakteri gram positif dan gram negatif termasuk Escherichia coli, Klabsiela, S. Aureus dan Proteus. Antibiotik golongan sefalosporin sering digunakan sebagai antibiotik profilaksis karena spektrum kerjanya yang cukup luas dan dirasa efektif (Wattimena, 2001).

Rekomendasi dari WHO (2003) menyatakan antibiotik profilaksis unruk bedah khususnya bedah sesar ialah dari golongan penisilin yaitu ampisilin dan golongan sefalosporin generasi pertama yaitu sefazolin. Hal ini di dukung oleh pernyataan oleh Kemenkes (2011) yang menyatakan rekomendasi penggunaan sefalosporin generasi pertama dan generasi kedua untuk profilaksis bedah. Pada kasus tertentu yang dicurigai melibatkan bakteri anaerob dapat ditambahkan metronidazol. Tidak dianjurkan menggunakan sefalosporin generasi ketiga dan generasi keempat, golongan karbapenem dan golongan kuinolon untuk profilaksis bedah. Selain itu, penggunaan antibiotik profilaksis pada pelaksaan bedah sesar termasuk dalam Highly Recommended. Dalam kategori Highly Recommended, antibiotik dinyatakan terbukti tegas menurunkan morbiditas, menurunkan biaya perawatan dan menurunkan konsumsi antibiotik secara keseluruhan. Akan tetapi dalam penelitian ini masih ditemukan beberapa pasien yang tidak mendapatkan antibiotik profilaksis.

\section{KESIMPULAN}

Berdasarkan hasil penelitian yang telah dilakukan, maka dapat disimpulkan bahwa :

1. Pasien yang melakukan bedah sesar terbanyak berdasarkan usia ialah pada rentang usia 20-35 tahun.

2. Pasien yang melakukan bedah sesar terbanyak berdasarkan status paritas atau frekuensi kehamilan ialah wanita dengan kehamilan kedua (primipara).

3. Pasien yang melakukan bedah sesar terbanyak berdasarkan indikasi medis ialah pasien dengan indikasi bedah sesar berulang.

4. Antibiotik profilaksis yang digunakan terbanyak ialah antibiotik golongan sefalosporin generasi ketiga yaitu sefotaksim.

\section{DAFTAR PUSTAKA}

1. BKKBN. (2007). Keluarga Berencana dan kontrasepsi. Cetakan ke-5.Jakarta. Pustaka sinar harapan

2. Caughey AB (2001), Risk of Vaginal Birth After Caesarean http://www.bmj.com/content/early/2001/12/31

3. Departemen Kesehatan RI. 2010. Survey Demografi Kesehatan Indonesia . Jakarta.

4. Gordon, R.E. \& Gordon, K.K. 2012. Social Factors in the Prediction and Treatment of Emotional Disorders of Pregnancy. Am J Obstet Gynecol, 107:1074-83. 
5. Hidayat, A. Aziz Alimul. (2009). Pengantar Kebutuhan Dasar Manusia. Salemba Medika. Jakarta. Hal 81-113, 213-222.

6. HoanTjay, T. Rahardja K. 2002. Obat- Obat Penting : Khasiat, Penggunaannya dan Efek Sampingnya. Ed 5. Jakrata : PT Elex Media Computindo.

7. Kemenkes. 2011. Pedoman Umum Penggunaan Antibiotik. Kementerian Kesehatan Republik Indonesia; Jakarta.

8. Mugford, M., Kingston, J. \& Chalmers, L., 1989, Reducing the incidence of infection after caesarean section: implications of prophylaxis with antibiotics for hospital resources, $B M J, 299,1003-1006$.

9. Prasetya, D.B., 2013, Efektifitas Penggunaan Antibiotik Profilaksis Pada Pasien Sectio Caesarea Elektif Di Rumah Sakit Sidoarjo, Jurnal Ilmiah, Surabaya: Fakultas Farmasi, Universitas Surabaya.

10. Rasjidi, imam. 2009. Manual Sectio Sesarea dan Laparatomi kelainan Adneksa. Jakarta : Sagung Seto.

11. Sheiner GI. Shoham-Vardi, Hallak M. Hershkowitz R. Katz M and Major M. 2001. Plasenta Previa : Obstetric risk and pregnancy outcome. J. Matern Fetal. Med 10 : 414-419.

12. Smaill, F., dan Hofmeyr, G.J. (2007). Antibiotic Prophylaxis For Cesarean Section. http://www.thecochranelibrary.com. Diakses tanggal 3 Maret 2015.

13. Sumapraja S dan Rachimhadi T. 2005. Perdarahan Antepartum dalam: Wiknjosastro H. Ilmu Kebidanan. Yayasan Bina Pustaka Sarwono Prawirohardjo. pp: 365-85: Jakarta.

14. Wattimena, J. R., Sugiarso, N. C., Sukandar, E. Y., Widianto, M. B., Soemardji, A. A., Setiadi, A. R. 2001. Farmakodinamika dan Terapi Antibiotika. Yogyakarta: Gadjah Mada University Press.

15. WHO, 2003, Managing Complications in Pregnancy and Childbirth: a Guide for Midwives and Doctors, 275-285, Geneva, World Health Organization. 